\title{
CHEMICAL COMPOSITION OF ICE POPS PRODUCED IN A MICROINDUSTRY FROM HIDALGO, MEXICO
}

\section{COMPOSICIÓN QUÍMICA DE PALETAS CONGELADAS PRODUCIDAS EN UNA MICROINDUSTRIA DE HIDALGO, MÉXICO}

\author{
Elizabeth Contreras L., Araceli Castañeda O., Zaira Cabrera C., \\ Javier Añorve M., Judith Jaimez O.
}

\begin{abstract}
Área Académica de Química, Instituto de Ciencias Básicas e Ingeniería, Universidad Autónoma del Estado de Hidalgo, Mineral de la Reforma, Hidalgo, Mexico.
\end{abstract}

\begin{abstract}
The chemical composition of water and milk based ice pops produced by a microindustry in Hidalgo, Mexico were determined. Fifteen samples of several flavors were analyzed. The proximate composition was carried out according AOAC techniques. The identification and quantification of fatty acids in the milk based ice pops was performed by Gas Chromatography provided with a flame ionization detector. Water based ice pops did not present a significant nutritional value. Regarding milk based ice pops all samples contained from 6.83 to $12.7 \%$ of fat and some samples showed interesting contents of protein (3.55 and 4.21\%). The fatty acid profile revealed higher contents of unsaturated fatty acids compared with saturated fatty acids. Trans fatty acids were detected in five of seven milk based samples, representing 20-60\% of total fatty acids. Analysis showed that the mixes used to prepare ice pops are different according to their flavor, kind, and amount of fruit which alters their nutritional value and the levels of trans-fatty acids.
\end{abstract}

Key words: chemical composition, fatty acids, gas chromatography, ice pops.

Este trabajo fue recibido el 11 de Octubre de 2011 y aceptado para ser publicado el 12 de Enero de 2012.

\section{INTRODUCTION}

Nowadays, ice cream has been included in the diet of many people around the world due mainly to their sensory properties. In Mexico, ice pops are frozen sweets on a stick (1). Ice pops as well as ice creams are classified according to the base used in their formulation which can be water or milk products. Milk based ice pops are those whose main ingredient is milk, cream or its derivatives. They have a nutritional value due to the contribution of protein, carbohydrates, fat and minerals mainly calcium and vitamins such as B2. The main ingredient of the other variety of ice pops is water. In some cases part of this water is substituted with fruit juice which improves the nutritional value.

Concerning milk based ice pops, fat is one of the most important ingredients because it contributes significantly to physicochemical and sensory properties. The fat content in ice cream is provided primarily by the milk fat, either whole cream, natural butter, anhydrous butter or oil butter (2). Ice cream also contains, in low proportion, vegetable fat, such as coconut oil, palm, palm kernel or vegetable oil blends (hydrogenated and nonhydrogenated) and other ingredients such as chocolate $(2,3)$. For all ice cream types, fats are the nutrients with the most variable content; therefore, these components make the difference in this kind of food (4-6).

Fat gives adequate texture properties to ice cream, provides a slight scent and acts synergistically with added flavorings, although it produces some decrease in shaking rate. This ingredient also plays an important role in flavor and in the solid structure formation during freezing, establishes the consistency, appearance and resistance to ice cream melting (2,7). During ice cream manufacturing, milk fat can be replaced by vegetable fat, reducing production costs but this affects their final composition and becomes a source of trans fatty acids (TFA) (8). The aim of this work was to provide information about chemical composition of ice pops produced 
locally in Hidalgo, Mexico, to know the nutritional value and the fatty acid composition of milk ice pops.

\section{MATERIALS AND METHODS Samples}

Fifteen samples of several flavors made with natural fruits (table 1) were obtained from a microindustry located in Sahagun City in the State of Hidalgo, Mexico. Samples were kept frozen until their analysis.

\section{Proximate analysis}

Protein, fat, ash, moisture and fiber content were determined to all samples according to the methodology established by AOAC (9).

\section{Mineral content}

The mineral content was measured only for milk based ice pops. $\mathrm{Ca}, \mathrm{Mg}$ and $\mathrm{P}$ content were determined by Inductively Coupled Plasm Mass Atomic Emission Spectrometry (ICP-MAES). Ashes obtained previously during the proximate analysis were redissolved in $10 \mathrm{~mL}$ of concentrated nitric acid and transferred to a volumetric flask. Volume was set to $50 \mathrm{~mL}$ with distilled water. The resulting solutions were kept at $4^{\circ} \mathrm{C}$ in plastic containers until their analysis.

Mineral standard solutions (Perkin Elmer) were

TABLE 1

Water and milk samples studied

\begin{tabular}{|cc|}
\hline & Ice pops \\
\hline Base & Flavor \\
\hline & Strawberry \\
& Mango-chili \\
& Soursoup \\
& Lemon \\
& Mango \\
& Guava \\
& Pineapple \\
& Kiwi \\
& Nut \\
& Cookie \\
& Pine nut \\
& Coconut \\
& Strawberry-cream \\
& Strawberry-nut \\
& Neapolitan \\
\end{tabular}

TABLE 2

Standard solutions of $\mathrm{Ca}, \mathrm{Mg}$ and $\mathrm{P}$

\begin{tabular}{|cccc|}
\hline Standard solution & $\mathbf{C a}(\mathbf{m g} / \mathbf{L})$ & $\mathbf{M g}(\mathbf{m g} / \mathbf{L})$ & $\mathbf{P}(\mathbf{m g} / \mathbf{L})$ \\
\hline Blank & 0 & 0 & 0 \\
1 & 10 & 2 & 0.2 \\
2 & 20 & 4 & 0.4 \\
3 & 30 & 6 & 0.6 \\
4 & 40 & 8 & 0.8 \\
\hline
\end{tabular}


prepared in nitric acid (3\%): $\mathrm{Ca}$ and $\mathrm{Mg} 1000 \mathrm{ppm}, \mathrm{P}$ $326.6 \mathrm{ppm}$ (table 2). Quantification was carried out in a Spectrophotometer Perkin Elmer, Optima 3000 XL. Wave lengths used were $422.673 \mathrm{~nm}$ (Ca), $213.618 \mathrm{~nm}$ $(\mathrm{Mg})$ and $259.940 \mathrm{~nm}(\mathrm{P})$. Detection limits were Ca, 0.1 $\mathrm{mg} / \mathrm{L}, \mathrm{Mg} 0.2 \mathrm{mg} / \mathrm{L}$ and $\mathrm{P} 0.05 \mathrm{mg} / \mathrm{L}$.

\section{Lipid profile of milk based ice pops}

The identification and quantification of fatty acids from milk based ice pops were realized by Gas Chromatography with a Flame Ionization Detector.

\section{Lipid extraction and fatty acid methylation}

Five grams of each ice pop sample were placed in a test tube adding $3.75 \mathrm{~mL}$ of a chloroform-methanol mixture $(1: 2 \mathrm{v} / \mathrm{v})$. This mixture was shaken in a vortex mixer for one minute followed by the addition of 1.25 $\mathrm{mL}$ of chloroform, and then it was shaken again for another minute until total lipid sample separation was achieved. All tubes were centrifuged at $4000 \mathrm{rpm}$ for 5 minutes. The aqueous phase was discarded and $5 \mathrm{~mL}$ of chloroform-methanol mixture were added. The tubes were shaken in a vortex for one minute. The lipid extract was transferred into clean test tubes. For the methylation a sample of $500 \mu \mathrm{L}$ of this extract was transferred to a tube. An acid transesterification (10) was carried out by adding $1 \mathrm{~mL}$ of Boron trifluoride solution and heating the tubes in a thermostatic bath set at $100{ }^{\circ} \mathrm{C}$ for $10 \mathrm{~min}$, yielding the methyl esters of fatty acids (FAME's).

FAME's recovery was carried out by adding $1 \mathrm{~mL}$ of hexane and $1 \mathrm{~mL}$ of MilliQ water saturated with hexane to each methylation tube which was vigorously shaken in a vortex for 10 minutes; subsequently, tubes were centrifuged at $4000 \mathrm{rpm}$ for $10 \mathrm{~min}$, separating the organic phase, which contained FAME's. A second wash with $2 \mathrm{~mL}$ of hexane saturated MilliQ water was performed; tubes were shaken vigorously in a vortex for 10 minutes and centrifuged again at $4000 \mathrm{rpm}$ for $10 \mathrm{~min}$. The organic phase with FAME's was transferred to conical bottom injection vials. FAME's extracts were concentrated with a nitrogen flow to avoid oxidation. The resulting mixture was dissolved in $1 \mathrm{~mL}$ of dichloromethane. A volume injection of $\mu \mathrm{L}$ was used for fatty acid identification and quantification.

\section{Identification and quantification of fatty acids}

Identification and quantification of FAME's was performed in a gas chromatograph (Perkin-Elmer, Autosystem XL model) equipped with a flame ionization detector (FID). A polar capillary column (SPTM -2560 $75 \mathrm{~m} \times 0.18 \mathrm{~mm}$ id $\times 0.14 \mu \mathrm{m}$ ) was used. The temperature program of the column was: initial temperature $150^{\circ} \mathrm{C}$, increasing $4^{\circ} \mathrm{C} / \mathrm{min}$ until $214^{\circ} \mathrm{C}$, holding for 2 minutes, then increasing $2.5^{\circ} \mathrm{C} / \mathrm{min}$ until $244^{\circ} \mathrm{C}$ and finally holding this temperature for 5 minutes.

Hydrogen was used as the carrier gas at a flow rate of $1 \mathrm{~mL}$ min-1. Likewise, the FAME's identification was performed by comparison with retention times of a standard mixture of FAME's injected previously. The FAME's quantification was carried out by normalization and transformation of the area to $\mathrm{mg}$ per $100 \mathrm{~g}$ of sample.

\section{Statistical analysis}

The statistical analyses were carried out using the ANOVA and Duncan tests $(\mathrm{P} \leq 0,05)$ in the Statgraphics Centuryon XVI.I program. At least three replications for each analysis were done.

\section{RESULTS AND DISCUSSION Proximate analysis}

The nutritional value of water based ice pops was not significant due to its low fat, protein, and fiber content. This is attributed to the kind of ingredients used in their preparation (water, sugar, corn syrup, flavorings and stabilizers). In the case of samples including natural fruits, the amount of fruit used is frequently too insignificant to influence the nutritional value in the final product. Carbohydrates content was similar for water and milk based ice pops.

Regarding milk based ice pops, all samples presented a high fat content $(6.83-12.17 \%)$ and in some cases an interesting content of protein (3.55 and $4.20 \%$ ) and fiber (8.81 and 3.2\%) as in the case of nut and coconut ice pops (table 3 ). The fat content found was due to the kind of fruit and mix used in their preparation while protein was given mainly by the fruit.

\section{Mineral content}

Milk based popsicles had a calcium content between 17.46 and $45.78 \mathrm{mg} / 100 \mathrm{~g}$ which are lower than those reported for ice cream (80-138 mg/100 mg) (11). Several studies have demonstrated that dairy products are a good source of bioavailable calcium because of its lactose content, $\mathrm{Ca} / \mathrm{P}$ ratio and to the $\mathrm{Ca}$-casein complex. However, the samples of this study do not demonstrate this due to the use of vegetable oils and dairy solids in lower proportion.

Magnesium was found in the order of 4.95 and $17.66 \mathrm{mg} / 100 \mathrm{~g}$; these values were closed to those reported recently for ice cream (9.3-11 mg/100g) (12). The high content of $\mathrm{Mg}$ in ice pops of this flavor was associated with the nut content since nuts are a source of this mineral $(13,14)$.

Phosphorus content was low (28.39-65.44mg/100) 


\begin{tabular}{|c|c|c|c|c|c|c|c|c|c|c|c|c|c|c|c|c|c|c|c|}
\hline 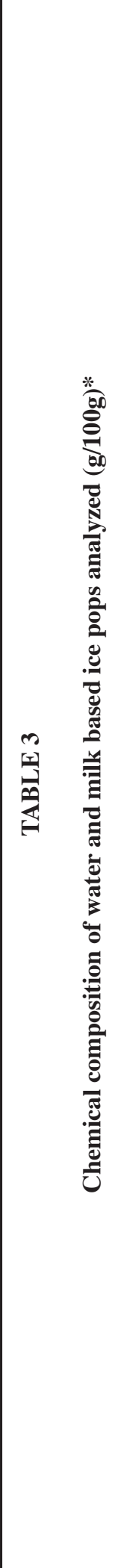 & 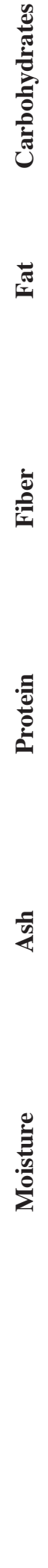 & 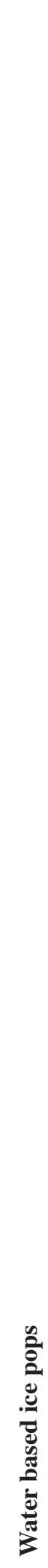 & 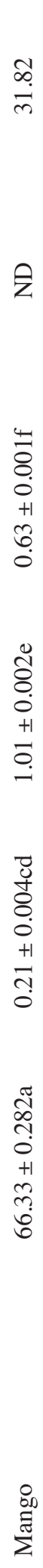 & 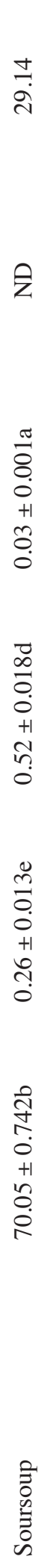 & $\begin{array}{l}\stackrel{0}{0} \\
\stackrel{2}{7} \\
\stackrel{0}{0} \\
+1 \\
\stackrel{1}{*} \\
\stackrel{2}{0}\end{array}$ & 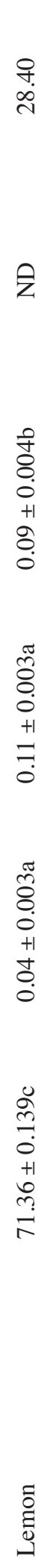 & 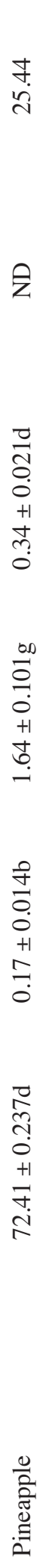 & 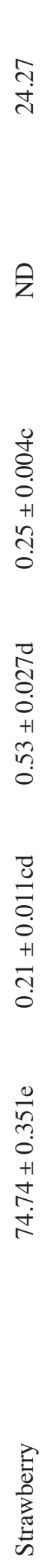 & $\begin{array}{l}\stackrel{0}{n} \\
0 \\
0 \\
+1 \\
a \\
\stackrel{1}{n}\end{array}$ & 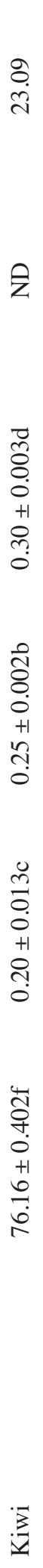 & 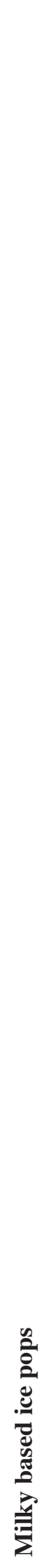 & 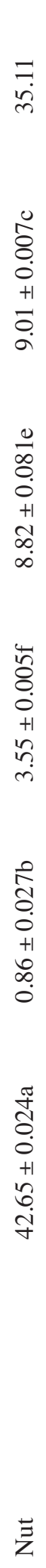 & 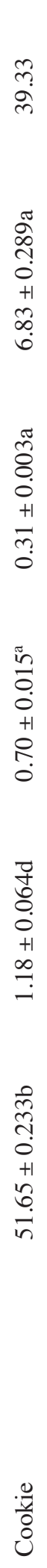 & 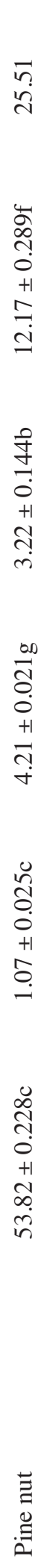 & 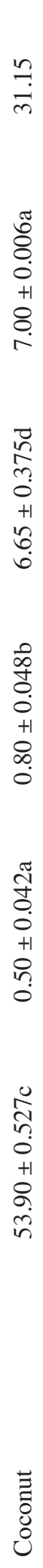 & 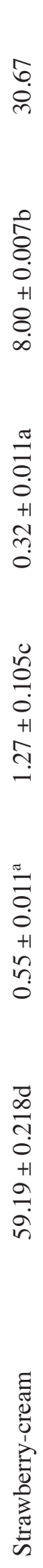 & $\begin{array}{l}\vec{n} \\
\tilde{n} \\
0 \\
0 \\
+1 \\
o \\
0 \\
+ \\
i \\
i n\end{array}$ & 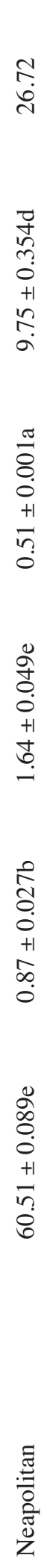 & 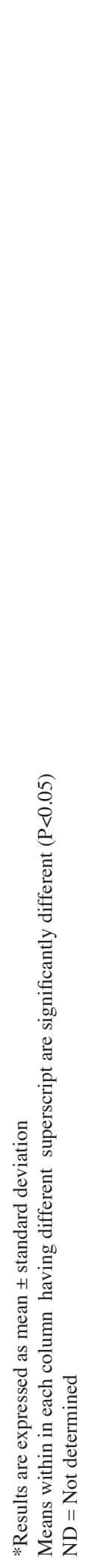 \\
\hline
\end{tabular}


compared with amounts reported for ice cream (45-150 $\mathrm{mg} / 100)$ (11). P and $\mathrm{Mg}$ amounts determined could come from dairy solids and from salts as sodium and magnesium phosphate used as additive to improve texture of final products (15).

\section{Fatty acids profile}

The chromatogram of fatty acids standards is presented in figure 1 . The fatty acids content (saturated, unsaturated and trans fatty acids) of ice pops analyzed are shown in table 4 . Values were found in the range of 6.1-11.8\%. Despite the total amount of ice pops showed a similar profile of fatty acids, their proportion of each acid was significantly different. In addition, the absence of linoleic and capric acids in some of them could point out that the mix used in their manufacturing process was a combination of different proportions of dairy and vegetable fat, depending on the flavor which was confirmed by the high proportion of palmitic acid and the presence of C18:1t. Figure 2 shows the chromatogram of fatty acids profile of cookie ice pop which presented a higher amount of $\mathrm{C} 18: 1 \mathrm{t}$. In the manufacturing process of the kind of cookies used in this sample formulation, partially hydrogenated fat is used (16).

A higher content of TFA was observed on pine nut and nut ice pops ( 31 and $21 \%$, respectively). The C18:2t was predominant as well as in the strawberry-nut flavor. This reflected an elevated proportion of dairy fat in the mix used in the manufacturing of these samples.

\section{CONCLUSION}

It seems to be that ingredients such as nut, pine nut and coconut as well as the mix are mainly responsible for the fatty acid profiles on the final products and the mixes used in ice pop manufacturing are not entirely made with dairy fat but in combination with vegetable fat which was demonstrated with the absence, in some cases, of C18:1n-9 cis and trans, C18:3n3 and C18:0, which are fatty acids proper from cow milk (17). So, it becomes necessary to establish measurement controls

\section{FIGURE 1}

\section{Chromatogram of a standard mixture of $\mathbf{3 7}$ methylated fatty acids}

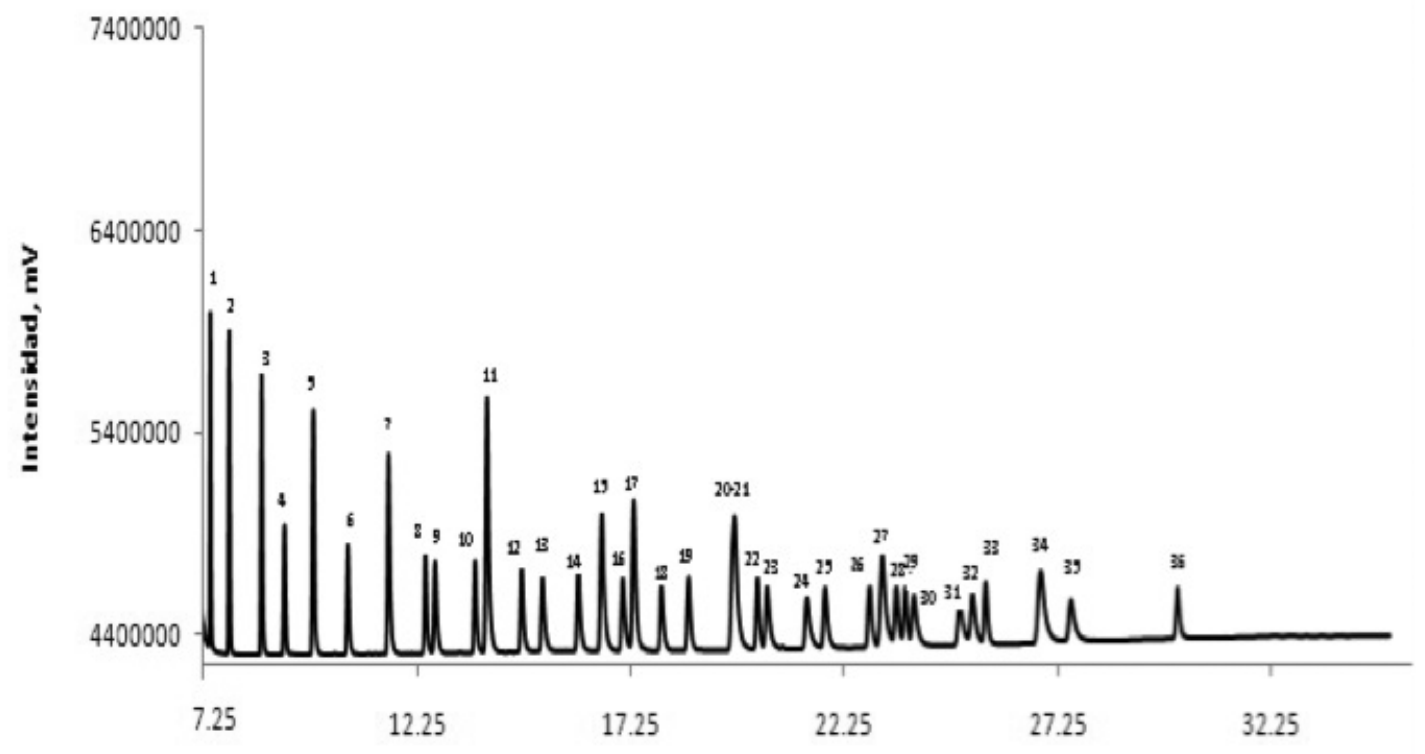

Tiempo de resolución, min

1 (C6:0), 2 (C8:0), 3 (C10:0), 4 (C11:0), 5 (C12:0), 6 (C13:0), 7 (C14:0), 8 (C14:1), 9 (C15:0), 10 (C15:1), 11 (C16:0), 12 (C16:1),

13 (C17:0), 14 (C17:1), 15 (C18:0), 16 (C18:1n9t), 17 (C18:1n9c), 18 (C18:2n6t), 19 (C18:2n6c), 20 (C20:0), 21 (C18:3n6),

22 (C18:3n3), 23 (C20:1), 24 (C21:0), 25 (C20:2), 26 (C20:3n6), 27 (C22:0), 28 (C20:3n3), 29 (C22:1n9), 30 (C20:4n6),

31 (C23:0), 32 (C22:2), 33 (C20:5n3), 34 (C24:0), 35 (C24:1) y 36 (C22:6n3) 


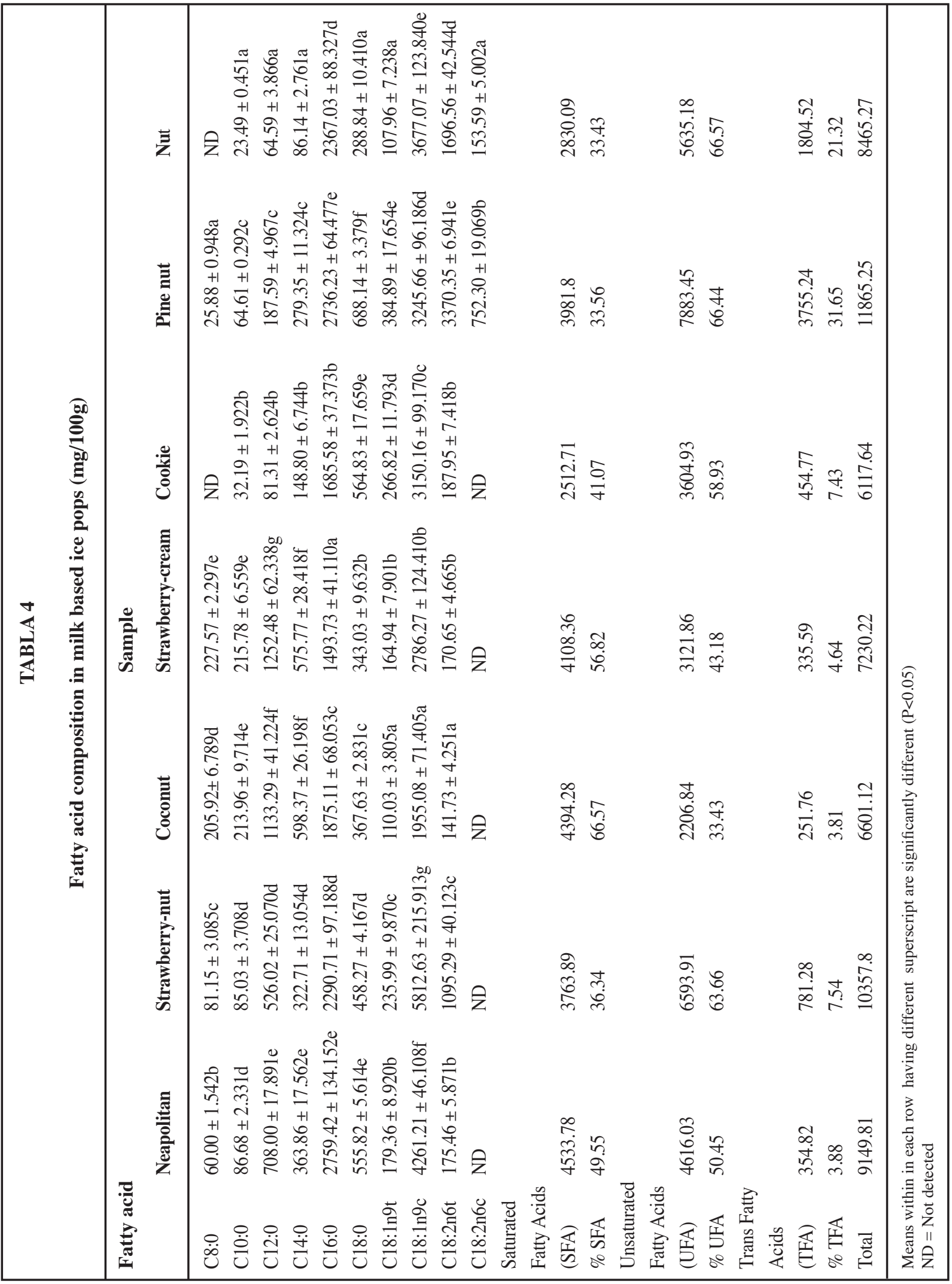


of raw materials used to produce mixes and ice pops since they are mass consumption products whose main market is children.

These results represent an important advance on the study of the TFA content in milky ice pops since there is little information about it. Due to the TFA implications on human health, their presence in the analyzed samples highlights the relevance of research in this field. This issue in México was considered by the Health Ministry which through the official norm NOM-043-SSA2-2005 (18) recommends to reduce fat/TFA consumption to prevent cardiovascular diseases. Regarding this, in 2008 the United States, through the Food and Drug Administration, began a promotion to make all food companies to include the TFA content legend in the labels of their products.

\section{RESUMEN}

Se determinó la composición química de paletas congeladas, en base agua y en base láctea, producidas por una microindustria en Hidalgo, México. Se analizaron quince muestras de diferentes sabores. La composición proximal se llevó a cabo de acuerdo a las técnicas de la AOAC. La identificación y cuantificación de ácidos grasos en las paletas base láctea se realizó por cromatografía de gases con detector de ionización de llama. Las paletas base agua no presentaron un valor nutricional significativo. Con respecto a las paletas base láctea, se observaron contenidos de grasa de 6.83 a $12.7 \%$; algunas presentaron valores interesantes de proteína (3.55 y $4.21 \%$ ). El perfil de ácidos grasos reveló altos contenidos de ácidos grasos insaturados comparados con los saturados. Cinco de las siete paletas de base láctea analizadas presentaron ácidos grasos trans, representando 20-60\% del total de ácidos grasos. Los análisis realizados han mostrado que las mezclas usadas para preparar las paletas son diferentes de acuerdo a su sabor, tipo y cantidad de fruta la cual modifica el valor nutricional y el nivel de ácidos grasos trans.

Palabras clave: composición química, ácidos grasos, cromatografía de gases, paletas congeladas.

\section{FIGURE 2}

\section{Chromatogram of fatty acids from cookie popsicle}

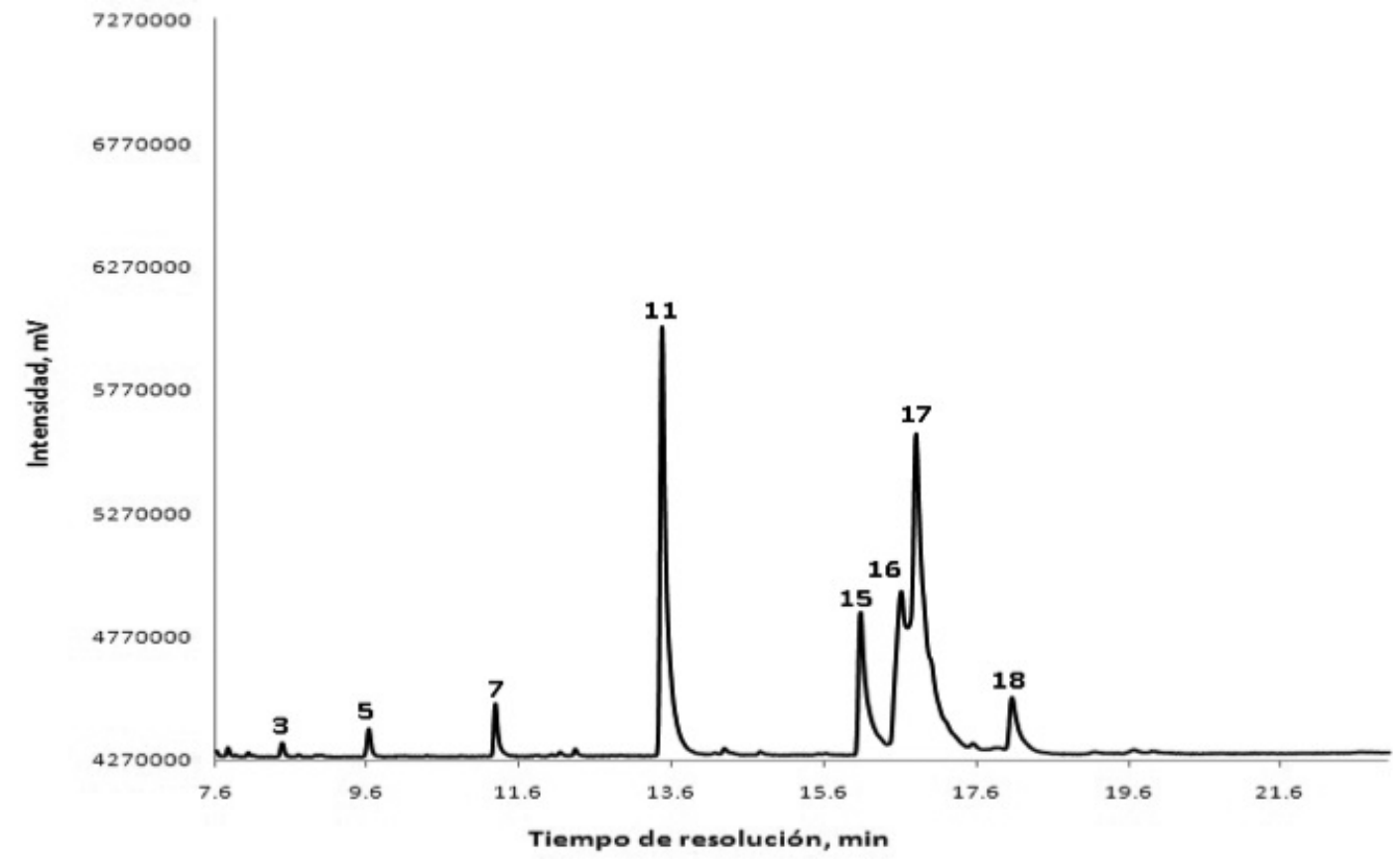

3 (C10:0), 5 (C12:0), 7 (C14:0), 11 (C16:0), 15 (C18:0), 16 (C18:1n9t), 17 (C18:1n9c) y 18 (C18:2n6t) 
Corresponding author:

Professor

Judith Jaimez O

Área Académica de Química

Instituto de Ciencias Básicas e Ingeniería

Universidad Autónoma del Estado de Hidalgo

Mineral de la Reforma, Hidalgo, Mexico

Tel. 00527717172000 ext. 2512

Fax 00527717172000 ext 6502

E-mail: jjaimez@uaeh.edu.mx

\section{BIBLIOGRAPHY}

1. Norma Oficial Mexicana NOM-036-SSA1-1993. Bienes y servicios. Helados de crema, de leche o grasa vegetal, sorbetes y bases o mezclas para helados. Especificaciones sanitarias. Secretaría de Salud. Diario Oficial de la Federación. México,DF.

2. Goff HD. Fox, PF, McSweeney, PLH eds. Advanced Dairy Chemistry. Volume 2. Lipids, Springer, USA, 2006, p. 441-50.

3. Kirk RS, Sawyer R, Egan H. Composición y Análisis de Alimentos de Pearson. CECSA, México, 2005.

4. Koxholt MMR, Eisenmann B, Hinrichs J. Effect of the fat globule sizes on the meltdown of ice cream, J Dairy Sci 2001; 84: 31-7.

5. Ruger PR, Baer RJ, Kasperson, KM. Effect of double homogenization and whey protein concentrate on the texture of ice cream, J Dairy Sci 2002; 85: 1684-92.

6. Olsen DW, White CH, Watson CE. Properties of frozen dairy desserts processed by microfluidization of their mixes. J Dairy Sci 2003; 86: p. 1157-62.

7. Walstra P, Geurts TJ, Noomen A, Jellema A, Van Boekel M. Ciencia y Tecnología de los Productos Lácteos. Acribia, España, 2007.

8. Alonso L, Fraga MJ, Juárez M, Carmona P. Fatty acid composition of Spanish shortenings with special emphasis on trans unsaturation content as determined by Fourier Transform Infrared Spectroscopy and Gas Chromatography. J Am Oil Chem Soc 2002; 79: 1-6.

9. AOAC. Official Methods of Analysis of the Association of Official Analytical Chemist. Published by AOAC, Inc. Helrich K. (Editor) (15th ed.). Arlington, 1990, Vol. I and II. Pp 80-81, 777, 851. USA.

10. Metcalfe LD, Schmitz AA. The rapid preparation of fatty acid esters for gas chromatographic analysis, Anal Chem 1961; 33: 363-4.

11. Madrid VA, Cenzano CI. Helados: elaboración, análisis y control de calidad. Mundi Prensa, España, 2003.

12. González CMJ. Valor nutritivo de los helados. Su integración en la dieta saludable, Ámbito Farmacéutico Nutr 2007; 26(8):86-92.

13. Mataix VJ, Carazo ME. Nutrición para educadores. Segunda edición. Ediciones Díaz de Santos, España, 2005.

14. Melvin HW. Nutrición para la salud, la condición física y el deporte. Paidotribo, España, 2002.

15. Marshall RT, Goff HD, Hartel RW. Ice Cream. Sixth edition. Kluwer Academic/Plenum Publishers, New York, 2003.

16. Banstransfats.com. Comments On Advanced Notice Of Proposed Rulemaking Regarding Trans Fat Labeling. Comments to FDA. California, USA, 2003.

17. Thurnhofer S, Lehnert K, Vetter W. Exclusive quantification of methyl-branched fatty acids and minor 18:1-isomers in foodstuff by GC/MS in the SIM mode using 10,11dichorounecanoic acid and fatty acid ethyl esters as internal standards. Eur Food Res Technol 2008; 226: 975-83.

18. Norma Oficial Mexicana NOM-043-SSA2-2005. Bienes y Servicios. Servicios básicos de salud, promoción y educación para la salud en materia alimentaria. Criterio para brindar orientación. Diario Oficial de la Federación. México, DF. 